\title{
Pengelolaan Keuangan Desa Melalui E-Village Budgeting di Kabupaten Banyuwangi
}

\author{
(Village Financial Management By E-Village Budgeting in Banyuwangi District) \\ Munfarida Rizky Mutamimmah, Alwan Sri Kustono ${ }^{1}$, Rochman Effendi \\ Jurusan Akuntansi, Fakultas Ekonomi dan Bisnis, Universitas Jember (UNEJ) \\ Jalan Kalimantan 37, Jember 68121 \\ E-mail: munfaridar@gmail.com
}

\begin{abstract}
This study aims to determine village financial management in Srono Sub District of Banyuwangi District by using e-Village Budgeting system and the effectiveness of using that system. This study uses primary data was collected from respondent's answers on interview was conducted with the parties concerned on village financial management in Srono Sub District of Banyuwangi District. Methods of data analysis is using descriptive with qualitative approaches and triangulation as a test of data validity. The results showed that village financial management by e-Village Budgeting consists of the process of planning, administration, and accountability of APBDesa. By using e-Village Budgeting village financial management becomes more effective and efficient.
\end{abstract}

Keywords : e-Village Budgeting, Management and Village Financial

\section{Pendahuluan}

Sunarsip (2001) menyatakan bahwa terjadinya krisis ekonomi di Indonesia disebabkan oleh tata kelola yang buruk (bad governance) pada sebagian besar pelaku ekonomi (publik dan swasta). Salah satu usaha untuk memulihkan kondisi ekonomi, sosial dan politik adalah dengan mengembalikan kepercayaan masyarakat kepada pemerintah dengan mewujudkan suatu pemerintahan yang bersih dan berwibawa atau yang dikenal dengan istilah good governance.

Salah satu strategi untuk mewujudkan good and clean government adalah dengan menerapkan electronic government yang merupakan suatu inovasi dari sektor publik. E-government adalah penggunaan teknologi informasi oleh pemerintah untuk memberikan informasi dan pelayanan bagi warganya, urusan bisnis, serta hal-hal lain yang berkenaan dengan pemerintahan. Di Indonesia pelaksaan penggunaan teknologi informasi pada pemerintahan dimulai sejak diterbitkannya Instruksi Presiden No. 3 Tahun 2003 Tentang Kebijakan dan Strategi Nasional Pengembangan egovernment Indonesia. Melalui pengembangan egovernment, dilakukan penataan sistem pengelolaan serta proses kerja di lingkungan pemerintah pusat dan pemerintah daerah otonom dengan mengoptimalisasi pemanfaatan teknologi informasi yang terintegerasi.

Salah satu hasil pengembangan dari e-government adalah eVillage Budgeting. Sistem electronic Village Budgeting (eVB) Banyuwangi merupakan salah satu contoh inovasi menuju transparansi penganggaran dan monitoring pembangunan di pelosok desa. Sistem penganggaran berbasis online dilakukan seiring rencana kucuran APBN ke desa yang akan mendapatkan lebih dari $\mathrm{Rp} 1,4$ miliar per tahun sesuai amanat Undang-Undang Nomor 6 Tahun 2014 tentang Desa. Dari sisi regulasi, desa tidak lagi menjadi bagian dari Undang-Undang No. 32 tahun 2004 tentang Pemerintahan Daerah. Desa-desa di Indonesia akan mengalami reposisi dan pendekatan baru dalam pelaksanaan pembangunan dan tata kelola pemerintahannya..

Pada hakikatnya Undang-Undang Desa memiliki tujuan dan rekayasa yang memberikan kewenangan luas kepada desa dalam penyelenggaraan pemerintahan, pelaksanaan pembangunan, pembinaan kemasyarakatan, dan pemberdayaan masyarakat berdasarkan prakarsa masyarakat, hak asal usul, dan adat istiadat desa. Kebijakan ini memiliki konsekuensi terhadap proses pengelolaannya yang seharusnya dilaksanakan secara profesional, efektif dan efisien, serta akuntabel agar terhindarkan dari resiko terjadinya penyimpangan, penyelewengan dan korupsi. Laporan keuangan desa akan menjadi suatu bentuk kebutuhan transparansi yang merupakan syarat pendukung adanya akuntabilitas yang berupa keterbukaan (opennes) pemerintah desa atas aktivitas pengelolaan sumber daya publik. Namun pada kenyataannya permasalahan yang sering terjadi dalam penyelenggaraan pemerintahan desa adalah administrasi pengelolaan keuangan desa yang kurang tertib, sehingga menimbulkan penyimpangan penggunaan anggaran.

Sistem e-Village Budgeting yang menyinergikan keuangan dan pembangunan di tingkat desa dengan kabupaten diharapkan mampu melakukan monitoring anggaran, memastikan program pembangunan di desa sesuai dengan kebutuhan masyarakat dan menjamin penggunaan anggaran tetap sasaran serta mewujudkan transparansi di sektor publik. Terdapat tiga tahap dalam e-Village Budgeting di Kabupaten Banyuwangi yaitu perencanaan, penatausahaan, dan pertanggungjawaban.

Kabupaten Banyuwangi menjadi pelopor dalam pembuatan software aplikasi keuangan desa yang dibangun oleh kabupaten. Payung-payung hukum Kabupaten Banyuwangi untuk implementasi Undang-Undang Desa sangat baik dan dapat menjadi contoh bagi kabupaten lain di Indonesia untuk melaksanakan amanat Undang-Undang Desa. Penggunaan $e$ Village Budgeting juga sebagai sikap preventif dari

1 Corresponding Author 
penyelewengan Dana Desa dengan maksud untuk memberikan pemberdayaan kepada aparatur desa.

Secara khusus Banyuwangi telah menerapkan penganggaran secara online melalui electronic Village Budgeting sejak tahun 2015 dan telah diterapkan di 189 desa yang tersebar di 24 kecamatan di Kabupaten Banyuwangi, termasuk Kecamatan Srono. Kecamatan Srono terdiri dari sepuluh desa yang berlokasi di kota dan desa yang akan dijadikan sebagai objek penelitian sesuai dengan saran penelitian sebelumnya yaitu Septiyani (2017) untuk melihat keefektifan penggunaan e-Village Budgeting. Perbedaan lokasi tersebut dapat menjadi salah satu penentu dalam keberhasilan penerapan e-Village Budgeting. Hal itu dikarenakan adanya kesenjangan kualitas sumber daya manusia dan hambatan lain seperti kesenjangan akses internet antara desa yang berlokasi di kota dan di desa. Salah satu desa di Kecamatan Srono yaitu Desa Sukonatar merupakan desa tercepat dalam pencairan dana APBDesa di Kabupaten Banyuwangi untuk tahun anggaran 2017 karena memiliki sumber daya manusia yang dapat memanfaatkan kemudahan dari adanya teknologi tersebut. Oleh karena itu Kecamatan Srono akan menjadi obyek dalam penelitian ini yang akan mewakili kecamatan lain yang memiliki masalah yang sama di Kabupaten Banyuwangi.

\section{Metode}

\section{Rancangan Penelitian}

Metode yang digunakan adalah metode deskriptif dengan pendekatan kualitatif. Penelitian kualitatif digunakan untuk mendapatkan pernyataan dan jawaban yang mendalam terhadap sebuah fenomena. Penelitian kualitatif tidak menggunakan sampel tetapi menggunakan situasi sosial yang terdiri dari 3 elemen yaitu, tempat, pelaku, dan aktivitas. Pelaku dalam penelitian ini yaitu kepala, sekertaris, dan bendahara di sepuluh desa yang ada di Kecamatan Srono Kabupaten Banyuwangi.

\section{Jenis dan Sumber Data}

Sumber data yang digunakan adalah data primer. Data primer yang dimaksud adalah hasil wawancara secara langsung dengan pihak-pihak yang terkait dengan pengelolaan keuangan desa di Kecamatan Srono Kabupaten Banyuwangi. Pihak-pihak tersebut diantaranya kepala, sekertaris, dan bendahara desa di sepuluh desa yang ada di Kecamatan Srono Kabupaten Banyuwangi. Selain itu data sekunder yang diperoleh peneliti secara tidak langsung melalui media perantara, namun hanya sebagai pendukung data primer berupa laporan.

\section{Teknik Analisis Data}

Penelitian ini menggunakan pendekatan analisis yang bersifat deskriptif. Penelitian yang menggunakan pendekatan tersebut harus menggambarkan kondisi penelitian yang sebenarnya, caranya yaitu dengan melakukan penelitian yang mendalam. Tahapan-tahapan dalam melaksanakan penelitian adalah pengumpulan data, reduksi data, uji keabsahan data, penyajian data, dan penarikan kesimpulan dan verifikasi.

\section{Uji Keabsahan Data}

Pengertian triangulasi menurut Moloeng (2004:330) adalah teknik pemeriksaan keabsahan data yang memanfaatkan sesuatu yang lain dalam membandingkan hasil wawancara terhadap objek penelitian. Triangulasi dapat dilakukan dengan menggunakan teknik yang berbeda yaitu wawancara, observasi dan dokumen (Nasution, 2003:115).

\section{Hasil dan Pembahasan}

\section{Perencanaan APBDesa}

Perencanaan APBDesa dimulai dari tilik dusun, Musdes, Musrenbangdes dan menjadi RKPDesa.Kemudian sekertaris desa akan membuat Rancangan Peraturan Desa Tentang APBDesa untuk disampaikan kepada kepala desa dan dimusyawarahkan bersama BPD. Setelah disetujui Rancangan Peraturan tersebut akan menjadi RAPBDesa dan diserahkan ke kecamatan untuk diverifikasi hingga akhirnya ditetapkan menjadi APBDesa. Baru setelah itu operator bisa mengentry RPD ke e-Village Budgeting.

\section{Pencairan APBDesa}

Pencairan dana APBDesa terdiri dari dua tahap. Tahap pertama yaitu setelah RAPBDesa diverifikasi dan ditetapkan menjadi APBDesa (sekitar bulan Maret atau April). Bendahara desa harus menyerahkan cetakan RPD dari $e$ Village Budgeting, RPJMDesa, RKPDesa, APBDesa tahun berjalan, buku profil desa, LPPDesa, Laporan Semester Akhir tahun sebelumnya per sumber anggaran, Laporan Pertanggungjawaban Realisasi Pelaksanaan APBDesa tahun anggaran sebelumnya minimal sudah selesai $80 \%$ ke DPM untuk diverifikasi. Kemudian DPM akan memberikan surat rekomendasi pencairan dana untuk diserahkan ke BPKAD. BPKAD juga akan melakukan verifikasi kembali hingga akhirnya dana APBDesa tahap pertama cair sebesar $60 \%$ melalui rekening giro milik desa dan bendahara desa hanya bisa menyimpan dalam bentuk kas sebesar 30\% dari total belanja desa di APBDesa.

Apabila kas tersebut habis bendahara bisa mencairkannya lagi dengan proses yang sama ditambah dengan SPJ penggunaan dana pencairan sebelumnya minimal telah terserap 80\% untuk pelaksanaan APBDesa. Proses tersebut terus berjalan hingga pencairan dana APBDesa tahap kedua sebesar $40 \%$ dari total APBDesa.

\section{Pelaksanaan dan Pengelolaan APBDesa}

Untuk pembayaran pelaksanaan kegiatan APBDesa TPK harus mengajukan RAB kepada kepala desa sebagai permohonan dana. Kemudian sekertaris desa akan melakukan verifikasi dan disahkan oleh kepala desa. Selanjutnya TPK bisa memesan barang/jasa sesuai dengan $\mathrm{RAB}$, baru setelah barang/jasa datang TPK bisa mengajukan SPP kepada kepala desa untuk ditandatangani dan diserahkan kepada bendahara yang berarti bendahara desa harus membayar pesanan tersebut. Operator harus merubah status SPP di e-Village Budgeting menjadi 'disetujui' dan baru bisa dilakukan pembayaran serta pencatatan pengeluaran di e-Village Budgeting. Selanjutnya TPK harus menyerahkan SPM sebagai bukti telah dilakukan pembayaran. Penatausahaan di e-Village Budgeting terdiri dari Buku Kas Umum, Buku Kas Pembantu Pajak, dan Buku Bank.

\section{Perubahan APBDesa}

Perubahan APBDesa dilakukan karena ada tambahan dana PAK dari pemerintah kabupaten. Dana PAK adalah dana surplus dari APBD yang dibagikan ke desa. Selain itu ada 
dana bantuan dari provinsi seperti Jalin Matra atau bantuan untuk fasilitas desa yang rusak, dana Reward yaitu penghargaan untuk lima puluh desa tercepat yang berhasil memenuhi target dalam memungut PBB dari masyarakat. Biasanya dana Reward akan cair sebelum pencairan APBDesa tahap dua atau sekitar bulan Agustus hingga September. Proses pengajuan hingga pencairan perubahan APBDesa sama dengan perencanaan APBDesa.

\section{Pelaporan dan Pertanggungjawaban APBDesa}

Pelaporan pelaksanaan APBDesa melalui e-Village Budgeting tahun berjalan secara otomatis akan tersusun bersama dengan proses penatausahaan, tinggal menambah bukti pendukung, seperti nota dan foto. Beberapa laporan yang harus dibuat oleh bendahara desa yaitu Laporan Realisasi Pelaksanaan APBDesa setiap satu semester. Laporan semester pertama dilakukan paling lambat akhir Juli tahun berjalan dan laporan semester akhir tahun paling lambat akhir Januari tahun anggaran berikutnya.

Kemudian Laporan Pertanggungjawaban Realisasi Pelaksanaan APBDesa kepada bupati melalui DPM setiap tahun paling lambat akhir bulan Januari tahun anggaran berikutnya. Laporan bulanan berupa Laporan Penyerapan dan Penggunaan Dana mulai dari setelah pencairan dana APBDesa tahap pertama hingga akhir tahun anggaran. Laporan ini dilakukan secara manual kemudian diserahkan ke kecamatan dan selanjutnya disalurkan ke DPM. Dan yang terakhir Laporan Keterangan Pertanggungjawaban yang dibuat secara manual untuk BPD dan telah disetujui kepala desa.

\section{Keuntungan Penerapan E-Village Budgeting}

E-Village Budgeting sangat membantu pekerjaan perangkat desa dalam pelaksanaan pengelolaan keuangan desa, proses yang awalnya begitu panjang dan rumit bisa menjadi mudah dan cepat. Rekening-rekening yang dibutuhkan dalam penatausahaan sudah tersedia dalam e-Village Budgeting dan untuk pelaporannya juga otomatis tersusun bersama dengan proses penatausahaan. Tingkat keakuratannya juga sangat tinggi dan tidak perlu khawatir akan kehilangan dokumen laporan tahun-tahun sebelumnya. Dengan sistem yang terintegrasi menjadikan pengelolaan keuangan desa melalui e-Village Budgeting lebih transparan, para stakeholder bisa memantau penggunaan dana APBDesa Untuk memantau perkembangan kegiatan yang berkaitan dengan APBDesa.

\section{Simpulan}

Penelitian ini bertujuan untuk mengetahui pengelolaan keuangan di sepuluh desa yang ada di Kecamatan Srono Kabupaten Banyuwangi dengan menggunakan sistem eVillage Budgeting dan keefektifan dari penggunaan sistem tersebut.

Hasil wawancara dan pembahasan yang telah peneliti jelaskan maka dapat disimpulkan bahwa pengelolaan keuangan desa melalui e-Village Budgeting dimulai dari tahap perencanaan melalui tilik dusun, Musdes, Musrenbangdes dan menjadi RKPDesa hingga RAPBDesa dan disetujui oleh camat menjadi APBDesa, barulah operator mengentry RPD ke e-Village Budgeting.

Tahap kedua yaitu pencairan APBDesa yang terdiri dari dua tahap, penatausahaan yang dilakukan oleh bendahara desa dan operator e-Village Budgeting melalui Buku Kas Umum, Buku Kas Pembantu Pajak, dan Buku Bank, serta melakukan tutup buku setiap akhir bulan secara tertib.

Bendahara desa wajib mempertanggungjawabkan uang melalui laporan pertanggungjawaban yang disampaikan setiap bulan kepada kepala desa dan paling lambat tanggal sepuluh bulan berikutnya. Bendahara desa juga harus menyampaikan laporan realisasi pelaksanaan APBDesa kepada kepala desa yang kemudian disalurkan kepada bupati melalui DPM. Kepala desa juga harus menyampaikan laporan pertanggungjawaban realisasi pelaksanaan APBDesa kepada bupati melalui DPM setiap akhir tahun anggaran.

Penerapan e-Village Budgeting ini membuat pengelolaan keuangan desa menjadi lebih efektif dan efisien. Selain itu juga memudahkan dalam pengendalian dan pengawasan, pola perencanaan desa lebih terarah dengan perencanaan sebelumnya.

Berdasarkan hasil penelitian yang telah dilakukan, penelitian ini tidak terlepas dari kelemahan dan keterbatasan, saran untuk penelitian yang akan datang sebaiknya menambah literatur mengenai pengelolaan keuangan desa melalui $e$ Village Budgeting. Selain itu, juga dapat melakukan penelitian yang lebih mendalam mengenai proses-proses pengelolaan keuangan desa melalui e-Village Budgeting, melakukan penelitian di lokasi yang berbeda atau yang lebih luas agar dapat menemukan fenomena lain yang terjadi dalam penerapan e-Village Budgeting dalam pengelolaan keuangan desa.

\section{Referensi}

Akbar dan Usman. 2009. Metode Penelitian Sosial. Jakarta: Bumi Aksara.

Asian Development Bank Institute. 2004.

Atmaja, Dinar. 2016. Analisis Pengelolaan Keuangan dan Kekayaan Desa (Studi Kasus di Desa Plesungan Kecamatan Gondangrejo Kabupaten Karanganyar). Skripsi. Surakarta: Program Studi Akuntansi Universitas Muhammadiyah Surakarta.

Basri, Ramlah. 2013. Analisis Penyusunan Anggaran dan Laporan Realisasi Anggaran pada BPM-PD Provinsi Sulawesi Utara. Skripsi. Manado: Universitas Samratulangi.

Buku Profil Pemerintah Kota Surabaya.

Cooper, Donald. R and Emory, C. William. 1995. Business Research Methods, $5^{\text {th }}$ ed., Richard D. Irwin, Inc.

Dewanti, Elsa. 2015. Analisis Perencanaan Pengelolaan Keuangan Desa Di Desa Boreng. Skripsi. Jember: Program Study Akuntansi Universitas Jember\}

Governmental Accounting Standarts Board (GASB).

Halim, Abdul dan Kusufi, Syam. 2012. Akuntansi Sektor Publik: Teori, Konsep dan Aplikasi. Jakarta: Salemba Empat.

Halim, Abdul. 2002. Akuntansi Sektor Publik Akuntansi Keuangan Daerah. Edisi Pertama. Jakarta: Salemba Empat.

HAW. Widjaja. 2003. Otonomi Desa Merupakan Otonomi yang Asli, Bulat dan Utuh. Jakarta: PT. Raja Grafindo Persada.

Indriantoro, Nur dan Supomo, Bambang. 2014. Metodologi Penelitian Bisnis untuk Akuntansi \& Manajemen. Yogyakarta: BPFE.

Instruksi Presiden No. 3 Tahun 2003.

Mardiasmo. 2009. Akuntansi Sektor Publik. Yogyakarta: Andi Persada.

Moleong, Lexy. J. 2004. Metode Penelitian Kualitatif. Bandung: Remaja Rosdakarya.

Moleong, Lexy. J. 2007. Metode Penelitian Kualitatif. Bandung: Remaja Rosdakarya. 
Mulyadi. 2001. Sistem Akuntansi. Edisi Ketiga, Cetakan Ketiga. Jakarta: Salemba Empat.

Nafarin, M. 2000. Penganggaran Perusahaan. Jakarta: Salemba Empat.

Nasution. 2003. Metode Penelitian Naturalistik Kualitatif. Bandung: Tarsito.

Nordiawan, Deddi, Iswahyudi dan Rahmawati, Maulidah. 2009. Akuntansi Pemerintahan. Jakarta: Salemba Empat

Nordiawan, Dedi. 2008. Akuntansi Sektor Publik. Jakarta: Salemba Empat.

Nordiawan, Dedi. 2010. Akuntansi Sektor Publik. Jakarta: Salemba Empat.

Peraturan Bupati Banyuwangi Nomor 15 Tahun 2015 tentang Pedoman Pengelolaan Keuangan Desa di Kabupaten Banyuwangi.

Peraturan Bupati Banyuwangi Nomor 51 Tahun 2015 tentang Perubahan Atas Peraturan Bupati Banyuwangi Nomor 15 Tahun 2015 tentang Pedoman Pengelolaan Keuangan Desa Di Kabupaten Banyuwangi.

Peraturan Menteri Dalam Negeri Nomor 113 tahun 2014 tentang Pengelolaan Keuangan Desa.

Peraturan Menteri Dalam Negeri Nomor 37 tahun 2007 tentang Pengelolaan Keuangan Desa Juncto Peraturan Menteri Dalam Negeri Nomor 113 tahun 2014 tentang Pengelolaan Keuangan Desa.

Peraturan Menteri Dalam Negeri Nomor 52 tahun 2015 tentang Pedoman Penyusunan Anggaran Pendapatan dan Belanja Daerah.

Peraturan Pemerintah Nomor 24 Tahun 2005 tentang Standar Akuntansi Pemerintah.

Pratiwi, Nur Ratih. 2016. Manajemen Keuangan Desa Melalui Inovasi Electronic Village Budgeting (Studi pada Badan Pemberdayaan Masyarakat dan Pemerintahan Desa Kabupaten Banyuwangi). Jurnal. Malang: Universitas Brawijaya.

Rosalina, Verina W. 2016. Implementasi E-Budgeting Terhadap Kinerja Instansi Pemerintah Kota Surabaya Dengan Pengendalian Internal Sebagai Variabel Moderasi. Skripsi. Surabaya: Universitas Airlangga.

Sagay, Brian. 2013. Kinerja Pemerintah Daerah dalam Pengelolaan Anggaran Pendapatan dan Belanja Kabupaten Minahasa Selatan. Jurnal. Manado: Universitas Sam Ratulangi.
Sanusi, Anwar. 2011. Metode Penelitian Bisnis, Jakarta: Salemba Empat.

Sedarmayanti. 2012. Good Governance "Kepemerintahan yang Baik". Bagian Kedua Edisi Revisi. Bandung: CV Mandar Maju.

Septiyani, Ayu Dwi. 2017. Pengaruh Penggunaan E-Village Budgeting terhadap Kinerja Aparatur Desa di Kabupaten Banyuwangi dengan Pengendalian Internal sebagai Variabel Pemoderasi. Skripsi. Jember: Universitas Jember

Shim, Jae K. and Siegel, Joel G. 2011. Budgeting Basics and Beyond Fourth Edition. New Jersey: John Wiley \& Sons, Inc.

Standar Akuntansi Pemerintah Pernyataan Nomor 02 Tahun 2005 tentang Laporan Realisasi Anggaran.

Sugiyono. 2008. Metode Penelitian Kunatitatif Kualitatif dan R\&D. Bandung: Alfabeta.

Sugiyono. 2010. Metode Penelitian Kuantitatif Kualitatif \& RND. Bandung: Alfabeta.

Sunarsip. 2001. Corporate Governance Audit: Paradigma Baru Profesi Akuntansi dalam Mewujudkan Good Coorporate Governance. Media Akuntansi, No. 17/Th. VII.pp. II-VII.

Sutedi, Adrian. 2011. Good Corperate Governance. Jakarta: Sinar Grafika.

Tanjung, Hafiz Abdul. 2009. Akuntansi Pemerintahan Daerah. Bandung: Alfabeta

Undang-Undang Nomor 17 Tahun 2003 tentang Keuangan Negara.

Undang-undang Nomor 23 Tahun 2014 tentang Pemerintahan Daerah.

Undang-Undang Nomor 32 dan 33 Tahun 2004 tentang Pemerintahan Daerah.

Undang-Undang Nomor 58 Tahun 2005 tentang Pengelolaan Keuangan Daerah.

Undang-Undang Nomor 6 Tahun 2014 tentang Desa.

www.jpnn.com diakses pada tanggal 1 Maret 2017.

Zeyn. 2011. Pengaruh Good Government dan Standar Akuntansi Pemerintahan terhadap Akuntabilitas Keuangan. Jurnal Trikonomika 10 (1): 52-62. 